\title{
The silica cycle in the Antarctic Ocean: is the Weddell Sea atypical?
}

\author{
Aude Leynaert ${ }^{1}$, David M. Nelson ${ }^{2}$, Bernard Quéguiner ${ }^{1}$, Paul Tréguer ${ }^{1}$ \\ ${ }^{1}$ URA CNRS 1513, Institut d'Etudes Marines, BP 452, F-29275 Brest Cedex, France \\ ${ }^{2}$ College of Oceanography, Oregon State University, Corvallis, Oregon 97331-5503, USA
}

\begin{abstract}
The lowest biogenic silica production rates in the Southern Ocean (average of 2.59 mmol Si $\mathrm{m}^{-2} \mathrm{~d}^{-1}$ ) have been recorded in an area of heavy ice cover along a transect through the Weddell Sea from Joinville Island to Cap Norvegia (November-December 1990). The associated biomass was also very low (concentrations $\leq 0.6 \mu \mathrm{mol} \mathrm{l}^{-1}$ for biogenic silica and $\leq 0.8 \mu \mathrm{g} \mathrm{l}^{-1}$ for chlorophyll $a$ ). Based upon these direct measurements of biogenic silica production rates and other data available from the marginal ice zone and open ocean areas, we estimated the annual production of biogenic silica in the northern Weddell Sea to be 810 to $870 \mathrm{mmol} \mathrm{m}^{-2} \mathrm{yr}^{-1}$. This leads to a revised estimate of the total annual

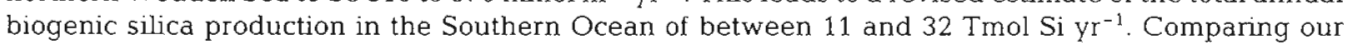
annual production estimate to previous estimates of vertical flux of opal in the Weddell Sea, we conclude that no more than $1 \%$ of the silica produced annually by phytoplankton in the upper water column reaches a depth of $800 \mathrm{~m}$. This is consistent with the general distribution of high accumulation rates of opal in Southern Ocean sediments which evidence an unexplained gap in the Weddell Sea. Thus, regarding the cycling of biogenic silica in the Southern Ocean, the Weddell Sea appears to be atypical.
\end{abstract}

\section{INTRODUCTION}

The major role of the Southern Ocean in the global production of biogenic silica (BSi) has been emphasized by many studies (review in Tréguer \& van Bennekom 1991). Recently Tréguer \& van Bennekom (1991) gave an estimate of $50 \mathrm{Tmol} \mathrm{Si} \mathrm{yr}^{-1}$ for the total annual production of BSi in the Southern Ocean, but large uncertainties remain mostly because of imprecisions in the estimates for several of the major subsystems that have been identified in this area (Tréguer \& Jacques 1992).

Much attention has been given to the silica cycle of the seasonal ice zone (SIZ) especially in the Weddell Sea. BSi standing stocks in that system have been reported for winter (Cota et al, 1992), spring (Nelson et al. 1987, Leynaert et al. 1991, Quéguiner et al. 1991, Tréguer et al. 1991), and late summer (Nelson et al. 1989). Direct measurements of BSi production rates in the Weddell Sea have been reported only for spring (Quéguiner et al. 1991, Tréguer et al. 1991). However 2 indirect estimates of seasonal BSi production have been calculated. By assuming interannual differences in winter nutrient distribution to be minimal, Jennings et al. (1984) estimated the average net production rate to be about $12 \mathrm{mmol} \mathrm{Si} \mathrm{m}^{-2} \mathrm{~d}^{-1}$ for a 60 to $90 \mathrm{~d}$ period, from the depletion of silicic acid in the surface layer of the eastern Weddell Sea (along the Greenwich meridian) from winter to spring. Tréguer \& van Bennekom (1991) estimated the mean silica production rate in summer (November-April) to be about $7 \mathrm{mmol} \mathrm{Si} \mathrm{m}^{-2}$ $\mathrm{d}^{-1}$ in the South Scotia area and at the Weddell-Scotia Confluence, based upon ${ }^{14} \mathrm{C}$ production rates and $\mathrm{BSi} / \mathrm{POC}$ (particulate organic carbon) ratios.

Indirect methods cannot give more than approximate values for 2 reasons. First, large spatial and temporal variations have been shown for BSi/POC ratios in the Weddell Sea (range: 0.01 to 1.00 by moles; Tréguer et al. 1990, 1991, Leynaert et al. 1991, with the maximum values corresponding to phytoplankton blooms dominated by highly silicified diatoms). Second, the exact duration of the different phases of the phytoplankton growth is not easy to determine and this could lead to substantial errors in seasonal production 
estimates. Thus, improved estimates of the annual BSi production for the Weddell Sea, the Southern Ocean or the world ocean require data based on direct measurements in the identifiable major subsystems, made during different seasons, and an improved understanding of how BSi production is related quantitatively to primary productivity, phytoplankton species composition and food-web dynamics.

The aims of this paper are: (1) to report standing stocks and production rates of biogenic silica and organic carbon in the Weddell Sea (along a transect from Joinville Island to Cap Norvegia; Fig. 1) for a prespring situation (i.e. in waters with significant ice cover during a period of ice retreat); (2) to explain the large seasonal variations of $\mathrm{BSi} / \mathrm{POC}$ ratios reported both for standing stocks and for production rates, in relation to phytoplankton growth, species composition and activity of the second trophic level; (3) to derive a new estimate of the dnnual biogenic silica production in the Weddell Sea; and (4) to propose a new silica budget for the Southern Ocean based on our Weddell Sea data and estimates from other Antarctic and subantarctic systems.

\section{METHODS}

All data were collected during the ANT IX-2 cruise aboard RV 'Polarstern' between 22 November and 20 December 1990. One transect (Fig. 1) was conducted across the Weddell Sea, from Joinville Island $\left(63^{\circ} 12^{\prime} \mathrm{S}, 53^{\circ} 41^{\prime} \mathrm{W}\right)$ to Cap Norvegia $\left(71^{\circ} 06^{\prime} \mathrm{S}\right.$, $\left.11^{\circ} 23^{\prime} \mathrm{W}\right)$. Eleven stations were sampled for biogeochemical measurements, of which only the first and the last were in open water. At each station, vertical profiles of temperature and salinity were obtained using a Neil Brown Mark IIIB CTD. Seawater samples were

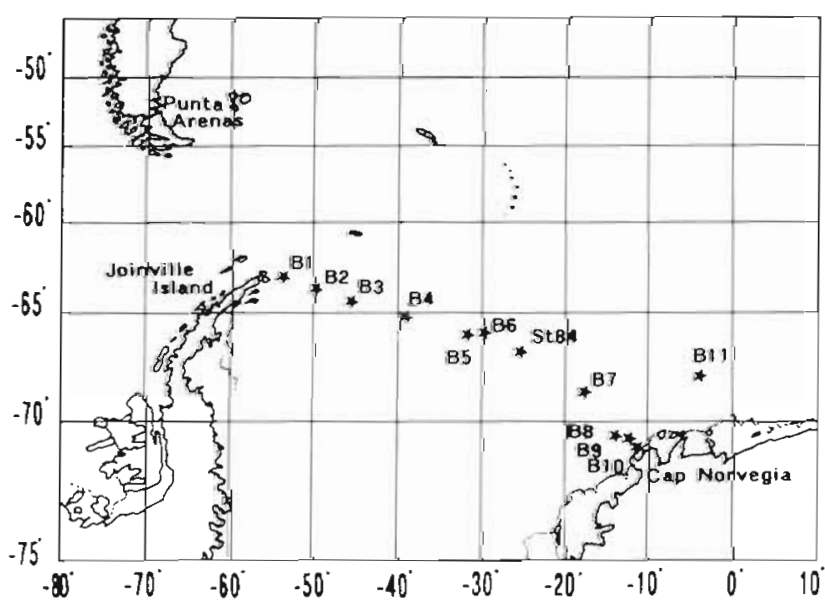

Fig. 1. Position of the biological stations during ANT IX/2 cruise (Nov-Dec 1990) collected in rosette-mounted, 121 Niskin bottles from 11 depths between the surface and $400 \mathrm{~m}$ to determine nutrient concentrations (silicate, nitrate, nitrite, ammonium, phosphate), chlorophyll a (chl a), POC, particulate organic nitrogen (PON), and BSi. For production experiments sampling depths were determined with reference to vertical irradiance profiles (respectively $100,25,10,3,1$ and $0.1 \%$ of surface incident light measured as photosynthetically available radiation (PAR) at wavelengths from 400 to $700 \mathrm{~nm}$ using a LICOR 92SB quantameter).

Nutrient analyses were performed immediately after collection, using the Alpkem RFA-300 continuous flow analysis system (Alpkem Corp. 1986). For chl a determinations $500 \mathrm{ml}$ were filtered onto Whatman GF/F filters, and immediately frozen on board at $-20^{\circ} \mathrm{C}$. Further analyses were performed at the Institut d'Etudes Marines (Brest, France), using a fluorometric method (Neveux 1976). At each station, Lugol's-preserved samples were obtained from surface water for phytoplankton species identification and counting (Utermöhl 1931).

POC and PON concentrations were measured by filtering $2.5 \mathrm{l}$ through $25 \mathrm{~mm}$ precombusted Whatman $\mathrm{GF} / \mathrm{F}$ filters. Each filter was dried at $60^{\circ} \mathrm{C}$ for $12 \mathrm{~h}$ and stored at $-20^{\circ} \mathrm{C}$ in glass vials. They were analysed using the combustion method of Strickland \& Parsons (1972) with a modified Carlo Erba analyser, model N1500 (blank $=0.1 \mu \mathrm{mol}^{-1}$ for $\mathrm{C}$ and $<0.02 \mu \mathrm{mol} \mathrm{l}^{-1}$ for N). BSi was collected by filtering 2.51 of seawater through a $47 \mathrm{~mm}$ Nuclepore membrane $10.4 \mu \mathrm{m}$ pore size); each filter was dried at $60^{\circ} \mathrm{C}$ for $12 \mathrm{~h}$ and stored in a polystyrene petri dish. BSi was determined using the $\mathrm{NaOH}$ digestion method (Paasche 1973) as modified by Nelson et al. (1989).

Production experiments were carried out under natural daylight conditions using a transparent Plexiglas incubator maintained at sea-surface temperature $\left( \pm 1^{\circ} \mathrm{C}\right)$ by a continous flow of surface seawater. In situ light conditions were simulated by using neutral density nickel screens $(100,25,10,3,1$ and $0.1 \%$ of surface light). For carbon production experiments, $300 \mathrm{ml}$ seawater collected in polycarbonate bottles was inoculated with $20 \mu \mathrm{Ci}(740 \mathrm{kBq})$ of $\mathrm{NaH}^{14} \mathrm{CO}_{3}$. After $24 \mathrm{~h}$ incubation, samples were filtered onto Whatman GF/F filters which were placed into scintillation vials. After addition of ACF Amersham scintillation cocktail, counting was done on board using a Packard 1600 TR scintillation counter.

For silica production experiments, 1.01 of seawater. from each depth was drawn into a polycarbonate incubation bottle covered with neutral density screen to simulate the irradiance at the depth from which it had been collected. Samples from most stations were enriched with $13 \mathrm{ml}$ of ${ }^{30} \mathrm{Si}$ tracer solution $(93.5 \%$, $1.5 \mathrm{mM})$. For Stns B4, B5 \& B6, ${ }^{29} \mathrm{Si}(95.6 \%, 1.45 \mathrm{mM})$ 
Table 1 . Bottom and photic depth $(0.1 \%$ of surface irradiance), hydrological parameters, and nutrient concentrations in surface waters for biological stations studied during the ANT IX/2 cruise

\begin{tabular}{|cccccccccc|}
\hline Stn & $\begin{array}{c}\text { Bottom } \\
(\mathrm{m})\end{array}$ & $\begin{array}{c}\text { Ice cover } \\
(0-10)\end{array}$ & $\begin{array}{c}\text { Photic depth } \\
(\mathrm{m})\end{array}$ & $\begin{array}{c}\text { Temperature } \\
\left({ }^{\circ} \mathrm{C}\right)\end{array}$ & $\begin{array}{c}\text { Salinity } \\
(\mathrm{PSU})\end{array}$ & $\begin{array}{c}\mathrm{PO}_{4} \\
(\mu \mathrm{M})\end{array}$ & $\begin{array}{c}\mathrm{Si}(\mathrm{OH})_{4} \\
(\mu \mathrm{M})\end{array}$ & $\begin{array}{c}\mathrm{NO}_{3} \\
(\mu \mathrm{M})\end{array}$ & $\begin{array}{c}\mathrm{NH}_{4} \\
(\mu \mathrm{M})\end{array}$ \\
\hline B1 & 405 & 0 & 123 & -1.48 & 34.40 & 2.05 & 72.4 & 29.5 \\
B2 & 2900 & 7 & 97 & -1.79 & 34.36 & 2.10 & 81.5 & 31.3 & 0.28 \\
B3 & 4454 & 7 & 77 & -1.79 & 34.38 & 2.06 & 80.2 & 29.6 & 0.15 \\
B4 & 4776 & 7 & 87 & -1.71 & 34.35 & 2.01 & 77.8 & 28.8 \\
B5 & 4786 & 7 & 98 & -1.65 & 34.37 & 2.03 & 73.1 & 27.6 \\
B6 & 4857 & 7 & 82 & -1.81 & 34.36 & 1.85 & 73.2 & 28.1 \\
B8 & 1222 & 9 & 130 & -1.81 & 34.32 & 1.12 & 61.1 & 30.0 & 0.14 \\
B9 & 369 & 6 & 150 & -1.76 & 34.33 & 2.08 & 61.2 & 30.2 & 0.09 \\
B10 & 480 & $<1$ & 158 & -1.88 & 34.30 & 2.08 & 62.5 & 30.5 \\
B11 & 4247 & 0 & 52 & -1.60 & 34.15 & 1.98 & 72.3 & 28.7 \\
\hline
\end{tabular}

was used. After the $24 \mathrm{~h}$ incubation period, each sample was filtered through a $0.4 \mu \mathrm{m}$ Nuclepore filter, dried at $60^{\circ} \mathrm{C}$ and stored in a polystyrene petri dish. The silicon isotope analysis was performed on a mass spectrometer (Nuclide Corp. Model 3-60) as described by Nelson \& Brzezinski (1990). The analytical uncertainty $(\Delta V)$ of the specific uptake rate $(V)$ is estimated as:

$$
V=\frac{{ }^{30} A_{\mathrm{f}}-{ }^{30} A_{n}}{t\left({ }^{30} A_{i}-{ }^{30} A_{n}\right)} \quad \frac{\Delta V}{V}=\frac{\Delta^{30} A_{1}+\Delta^{30} A_{n}}{\left({ }^{30} A_{f}-{ }^{30} A_{n}\right)}+\frac{\Delta t}{t}+\frac{\Delta^{30} A_{1}}{{ }^{30} A_{i}}
$$

where ${ }^{30} A_{f}=$ atom $\%{ }^{30} \mathrm{Si}$ of the final particulate silicon; ${ }^{30} A_{\mathrm{n}}=$ atom $\%{ }^{30} \mathrm{Si}$ of natural silicon; ${ }^{30} A_{\mathrm{i}}=$ initial atom ${ }^{30} \mathrm{Si}$ of the total (ambient plus labeled) silicic acid pool; $t=$ duration of the incubation (h).

Repetitive analysis of isotopic standards on our instruments indicates that the mass spectrometry determination of ${ }^{30} A_{\mathrm{f}}$ and ${ }^{30} A_{\mathrm{n}}$ is accurate to within \pm 0.03 atom $\%$. Time was always measured to within $1 \%$. The accuracy of the calculated ${ }^{30} A_{1}$ depends on that of the measured volume, concentration and isotopic composition of the tracer solution, the volume of the sample and the ambient silicate concentration (Nelson \& Goering 1977). For these samples the accumulated uncertainty in ${ }^{30} A_{1}$ is $\leq 4 \%$. Eq. 1 shows that the uncertainty in $V$ is $\leq 11 \%$ when $\left({ }^{30} A_{f}-{ }^{30} A_{n}\right)$ is $\geq 1.0$ atom $\%$.

\section{RESULTS}

\section{Ice coverage, hydrographic and chemical conditions}

For most stations, ice coverage ranged between 6 and 9/10 (Table 1). There was open water at Stn B1 situated at the western end of the transect near Joinville Island (Antarctic Peninsula), Stn B10 at the eastern end of the transect, close to Cap Norvegia and Stn B11, north from Stn B10. Stns B1 \& B10 are coastal stations (bottom depths are 405 and $480 \mathrm{~m}$ respectively). Stn $B 11$ is a typical oceanic station (bottom depth $4247 \mathrm{~m}$ ), situated in the seasonal ice zone.

Distributions of temperature, salinity and silicic acid in the upper $500 \mathrm{~m}$ are presented in Fig. 2a to c. We found:

(a) The Winter Water (Carmack \& Foster 1975) in the surface layer throughout the whole area (WW: $-1.84^{\circ} \mathrm{C}, 34.4 \mathrm{PSU}$ ), with silicic acid, nitrate and phosphate concentrations ranging from 61 to $80,27.6$ to 31.3 , and 1.85 to $2.12 \mu \mathrm{M}$ respectively (Table 1 ). The general domed structure of the isolines shown in Fig. 2 can be explained by the anticyclonic circulation of the Weddell gyre (Fahrbach et al. 1991), which is associated with an upwelling trend in the central zone (Stns B5 \& B6). There was no homogeneous mixed layer from Stns B2 to B9; this differs from the mid-winter situation (e.g. Muench 1990). As the winter water is progressively subjected to seasonal warming its characteristics change slightly; by late November it had become warmer (from -1.8 to $-1.6^{\circ} \mathrm{C}$ ) and fresher (from 34.4 to $34.3 \mathrm{PSU}$ ) due to ice and snow melting. However, at the western and eastern boundaries of the transect intense vertical mixing caused nearly vertical isolines of temperature and nutrients (Fig. 2a, c).

(b) The Warm Deep Water (Foster \& Carmack 1976) is characterized by a salinity maximum of 34.7 PSU and a temperature maximum of $0.8^{\circ} \mathrm{C}$ (at $150 \mathrm{~m}$ depth) in the eastern part of the transect and $0.4{ }^{\circ} \mathrm{C}$ in the west (G. Rohardt unpubl.), evidencing the inflow of the Weddell gyre in the east and the outflow in the west. In that water mass, nutrient concentrations were higher, reaching $110 \mu \mathrm{M}$ for $\mathrm{Si}(\mathrm{OH})_{4}, 33.8 \mu \mathrm{M}$ for $\mathrm{NO}_{3}$ and $2.34 \mu \mathrm{M}$ for $\mathrm{PO}_{4}$ (at $150 \mathrm{~m}$ depth). 


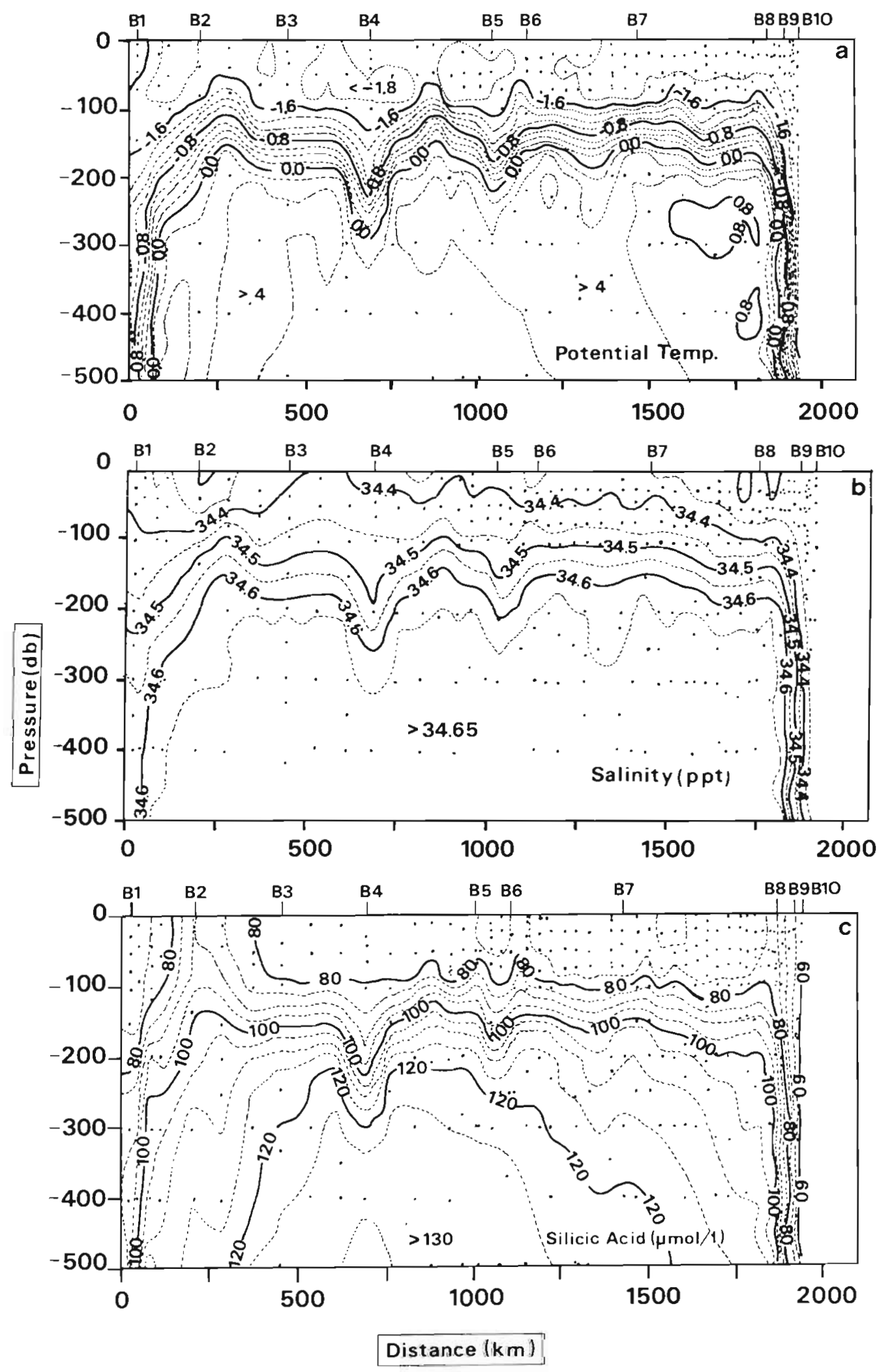

Fig. 2. (a) Potential temperature, (b) salinity and (c) silicic acid concentrations in the upper $500 \mathrm{~m}$ during the investigation period along the northeastern to southwestern transect across the Weddell Sea 


\section{Biomass distribution (chl a, BSi, POC, PON)}

Generally speaking, similar distributions were observed for chl $a, \mathrm{BSi}_{1} \mathrm{POC}$ and PON, although the maxima did not coincide for chl $a$, as compared with the other parameters (Fig. 3). Phytoplankton biomass (as indicated by $\mathrm{chl}$ a and $\mathrm{BSi}_{\text {; }}$ see also phytoplankton cell counts, Table 2) was very low and we did not encounter anything that could be characterized as a spring bloom. Stns B1 \& B11, which had characteristics significantly different from the others, showed a situation more advanced in the season with higher biomass: BSi concentrations at the surface were $0.47 \mu \mathrm{mol} \mathrm{l}{ }^{-1}$ at Stn B1 and $0.58 \mu \mathrm{mol} \mathrm{l}^{-1}$ at Stn B11 (not shown in Fig. 3), i.e. 3 to 5 times those at the other stations. In the same way, POC and PON reached their maximum values at the coastal station (B1): 8.40 and $0.80 \mu \mathrm{mol}^{-1}$ respectively. Chl a concentrations were also relatively high, reaching $0.64 \mu \mathrm{g} \mathrm{l}^{-1}$ at $\operatorname{Stn} \mathrm{B} 1$. The general biomass distribution in this portion of the Weddell Sea appears to have been almost symmetrical about the center of the gyre, situated around Stn B5. Concentrations of suspended particulate matter increased from the periphery to the center, where a chl a maximum was encountered $\left(0.76 \mu \mathrm{g} \mathrm{l}^{-1}\right)$ together with BSi concentrations higher than in the surrounding waters. Elsewhere, biomass was very low, $<0.2 \mu \mathrm{mol}^{-1}$ for BSi and $<0.14 \mu \mathrm{g} \mathrm{l}^{-1}$ for chl a. Surface POC and PON values also increased toward the center, ranging from 3.02 to $5.08 \mathrm{~mol} \mathrm{l}^{-1}$ for $\mathrm{POC}$ and from 0.33 to $0.61 \mu \mathrm{mol} \mathrm{l}^{-1}$ for PON (average: 4.43 and $0.49 \mu \mathrm{mol} \mathrm{l}^{-1}$ respectively). These concentrations are very similar to those found previously in the Weddell Sea marginal ice zone in winter (Cota et al. 1992). All biomass parameters (chl $a, \mathrm{BSi}, \mathrm{POC}$ and $\mathrm{PON}$ ) typically decreased with depth within the photic zone, except at the boundaries where vertical mixing resulted in nearly uniform concentrations.

Phytoplankton cell numbers at $10 \mathrm{~m}$ depth were in the order of $10^{5}$ cells $^{-1}$ (Table 2). The specific diversity (Frontier 1969) was high: $H=3.25 \pm 0.25$, suggesting a

Table 2. Cell counts (cells $1^{-1}$ ) in surface water samples from 6 stations. nd: not determined

\begin{tabular}{|lcccc|}
\hline Stn & $\begin{array}{c}\text { Nanophyto- } \\
\text { plankton }\end{array}$ & $\begin{array}{c}\text { Microphyto- } \\
\text { plankton }\end{array}$ & $\begin{array}{c}\% \text { empty } \\
\text { frustules of } \\
\text { total diatoms }\end{array}$ & $\begin{array}{c}\% \text { diatoms of } \\
\text { total micro- } \\
\text { phytoplankton }\end{array}$ \\
\hline B1 & $2.54 \times 10^{5}$ & $1.75 \times 10^{4}$ & nd & 94 \\
B5 & $3.29 \times 10^{5}$ & $1.83 \times 10^{4}$ & nd & 83 \\
B6 & $2.27 \times 10^{5}$ & $1.50 \times 10^{4}$ & 37 & 78 \\
B9 & $2.22 \times 10^{5}$ & $1.02 \times 10^{4}$ & 40 & 82 \\
B10 & $6.78 \times 10^{4}$ & $2.80 \times 10^{3}$ & 49 & 56 \\
B11 & $1.68 \times 10^{5}$ & $2.68 \times 10^{4}$ & 43 & 49 \\
\hline
\end{tabular}

population in a growing stage. Phytoplankton assemblages in all regions were dominated in number by small autotrophic nanoflagellates (Table 2). Microphytoplankton (20 to $200 \mu \mathrm{m}$ ) was dominated by small diatoms and Nitzschia curta was the most representative species. For example, at Stn B6, the cell densities were 6880,1200 and 1200 cells $l^{-1}$ for $N$. curta, $N$. longissima and $N$. kerguelensis respectively. However, a large amount of empty frustules (also dominated by $N$. curta) were observed, suggesting the important influence of biogenic matter released by melting ice and its role in seeding the water column (Lancelot et al. 1991).

\section{Production of organic carbon and biogenic silica}

We encountered a pre-spring biological situation confirmed by low rates of primary productivity. The photic layer (depth of $0.1 \%$ of surface irradiance) was very deep and displayed a large range of variations, from 52 to $158 \mathrm{~m}$ depth (Table 1). The photoperiod ranged from $20 \mathrm{~h}$ for the northern stations to $24 \mathrm{~h}$ for the southern ones. Vertical profiles of production rates usually differed for carbon and biogenic silica (Fig. 4). Unlike the rate of photosynthetic carbon production which is strongly light-dependent, as evidenced by the rapid decrease with depth (Figs. 4 \& 5a), the rate of BSi production was much more uniform in the water column (Figs. 4 \& 5b). As was the case for biomass distributions, higher rates of $\mathrm{BSi}$ production were encountered in open waters where they reached 0.09 and $0.05 \mu \mathrm{mol} \mathrm{Si} \mathrm{l}^{-1} \mathrm{~d}^{-1}$ (Stns B1 \& B11). Carbon primary production rates were also relatively high in

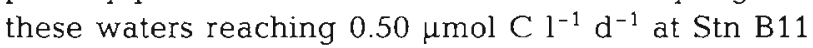
(Fig. 5).

Along the transect, a slight but noticeable increase in carbon and silica production rates was evident toward the center of the transect as shown by Fig. $5 \mathrm{a}, \mathrm{b}$. These

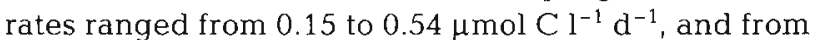
0.017 to $0.039 \mu \mathrm{mol} \mathrm{Si} \mathrm{l}^{-1} \mathrm{~d}^{-1}$ respectively, with maximum values being reached at $\mathrm{Stn} B 5$ for carbon and at Stn B6 for silica.

Integrated vertically for the photic zone, biogenic silica and carbon production rates show little spatial variability (Table 3). The integrated BSi production rates are the lowest ever reported for the Southern Ocean, averaging about $30 \%$ lower than those obtained by Nelson \& Gordon (1982) in the Antarctic Circumpolar Current (ACC) in very early spring, whereas those of carbon are comparable to those from Tréguer et al. (unpubl.) in autumn in the SIZ of the Weddell Scotia Sea. Carbon production rates were 3 to 10 times 

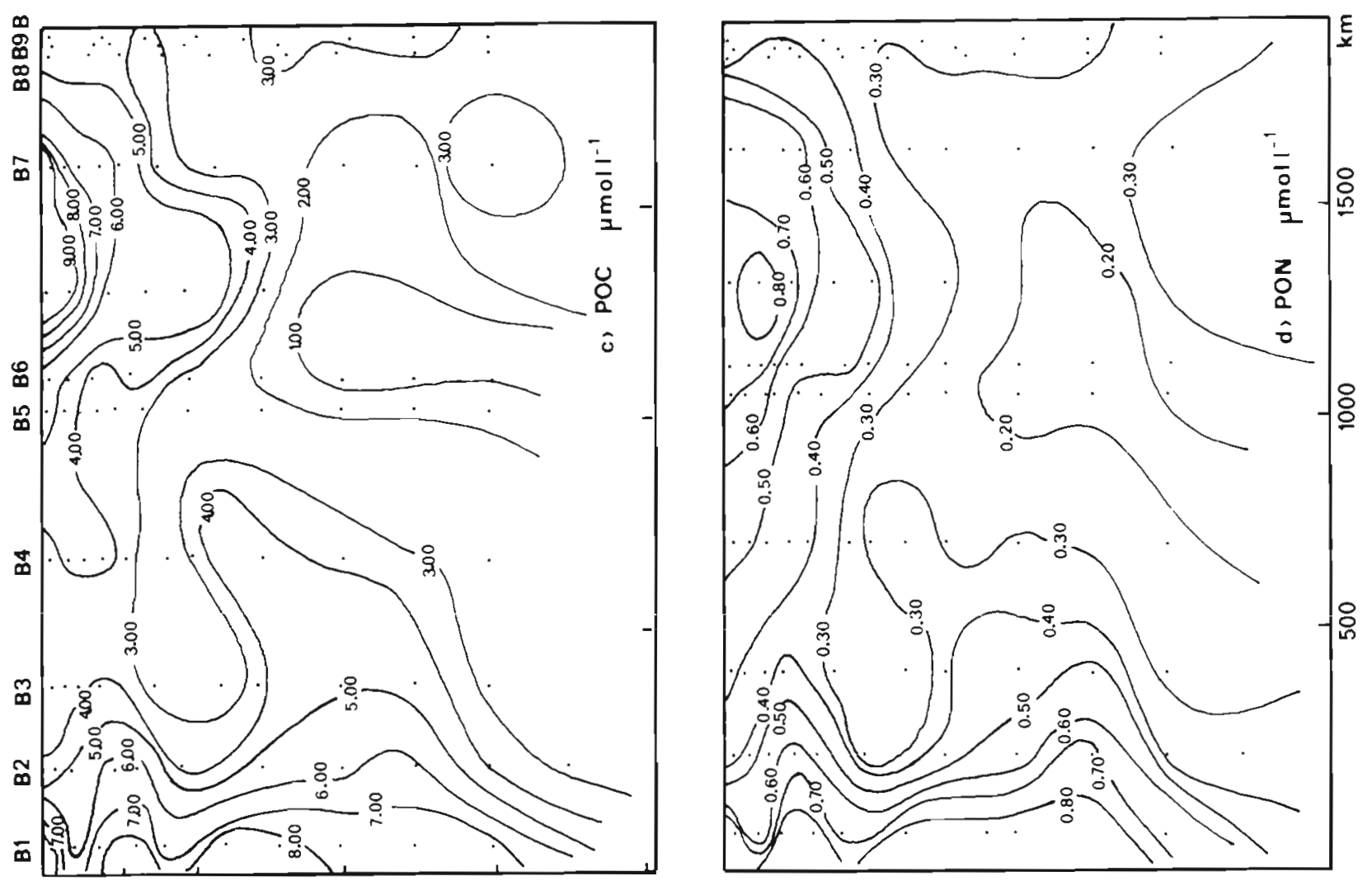

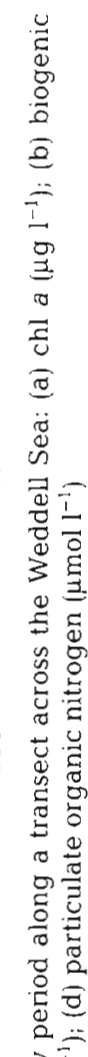
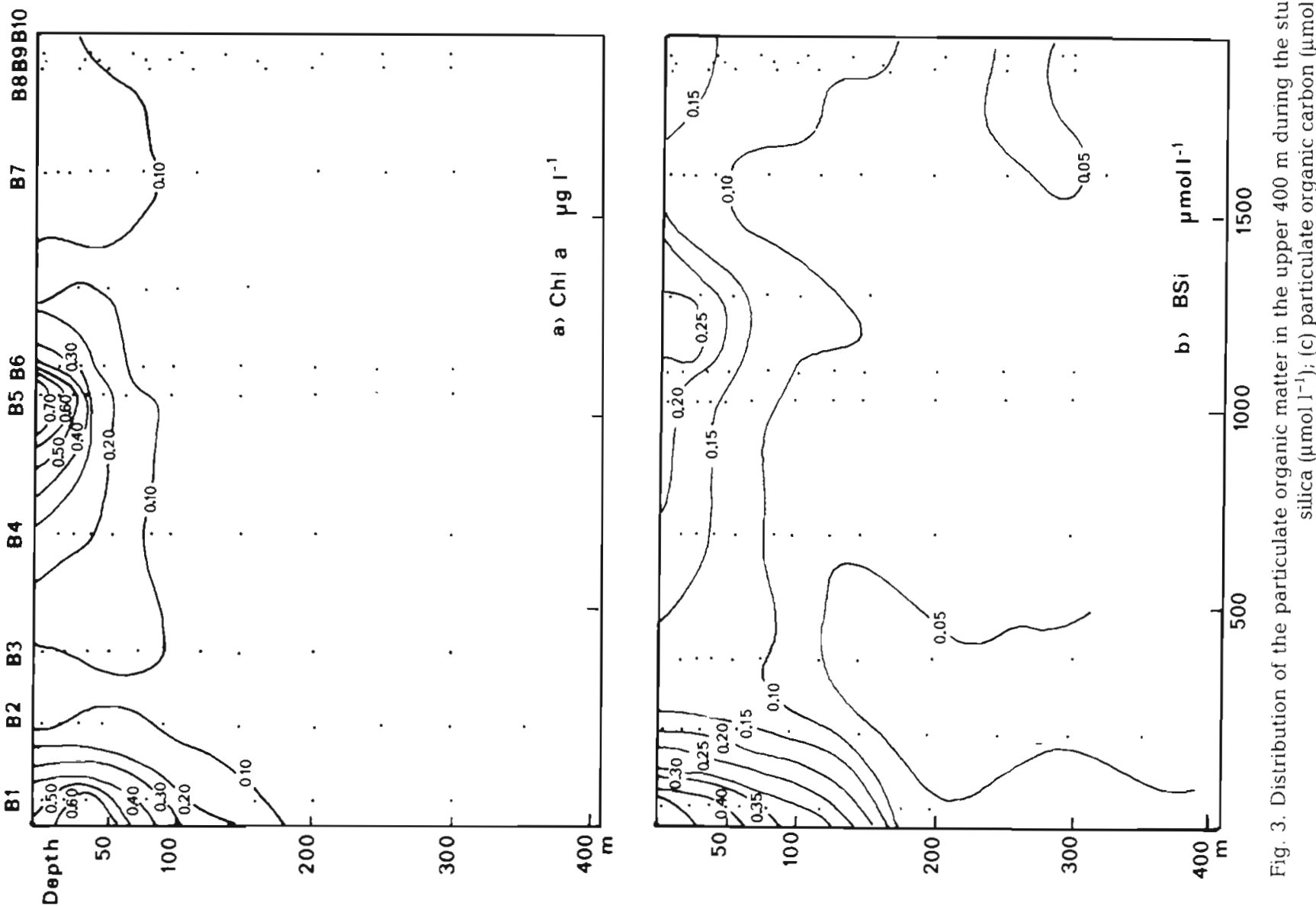

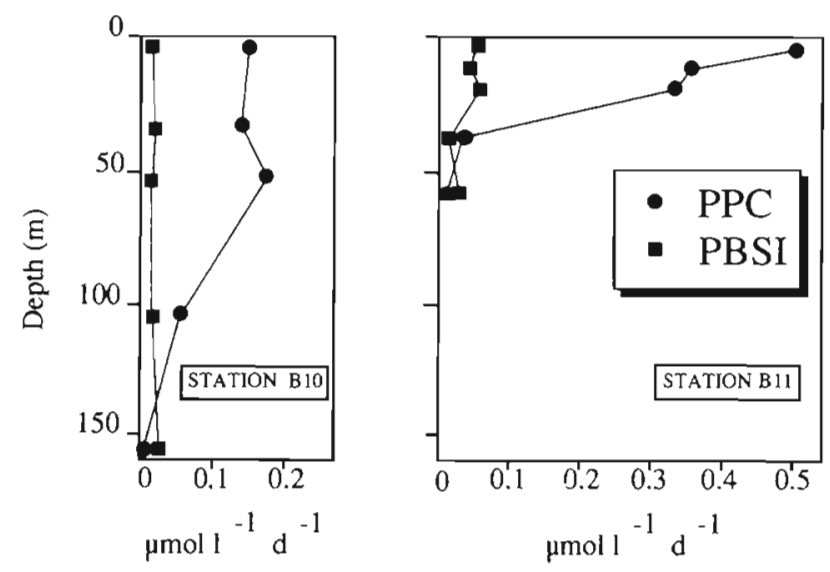

Fig. 4. Vertical profiles of biogenic silica production (PBSi) and carbon primary production rates (PPC) at Stns B10 \& B11

higher than those observed in the Weddell Sea in winter (Cota et al. 1992).

Stn B10, located in a narrow polynya, has a very deep photic zone $(158 \mathrm{~m})$ and is of particular interest: although very low biomass concentrations were found
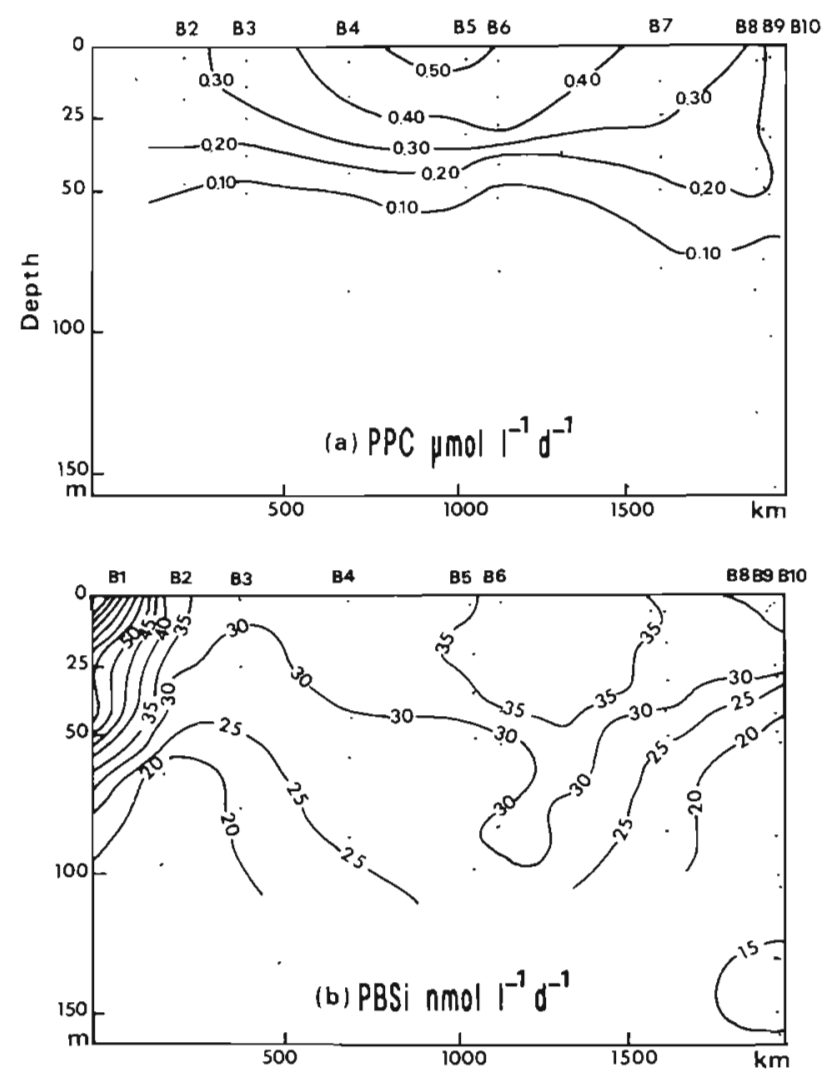

Fig. 5. Distribution of biogenic silica production (PBSi) and carbon primary production rates (PPC) in the photic layer, along a transect across the Weddell Sea during ANT IX/2 cruise
Table 3. Vertically integrated (in the photic depth) rates of biogenic silica production (PBSi) and carbon production (PPC). Specific growth rates are calculated as: $\mu=\log [(\mathrm{BSi}+\mathrm{PBSi}) / \mathrm{BSi}] \times 1 / \mathrm{t} \times 1 / \log (2)$

\begin{tabular}{|lccc|}
\hline Stn & $\begin{array}{c}\text { PBSi } \\
\left(\mathrm{mmol} \mathrm{m}^{-2} \mathrm{~d}^{-1}\right)\end{array}$ & $\begin{array}{c}\mu \\
\left(\mathrm{db} \mathrm{d}^{-1}\right)\end{array}$ & $\begin{array}{c}\mathrm{PPC} \\
\left(\mathrm{mmol} \mathrm{m}^{-2} \mathrm{~d}^{-1}\right)\end{array}$ \\
\hline B2 & 2.31 & 0.25 & 13.95 \\
B3 & 2.06 & 0.29 & 13.13 \\
B4 & 2.59 & 0.28 & 17.35 \\
B5 & 2.91 & 0.28 & 22.00 \\
B6 & 2.84 & 0.24 & 18.12 \\
B8 & 2.75 & 0.19 & 17.25 \\
B9 & 2.69 & 0.18 & 20.05 \\
B10 & 3.18 & 0.24 & 15.20 \\
B11 & 1.97 & 0.12 & 10.05 \\
Mean & 2.59 & 0.23 & 16.34 \\
SD & 0.38 & 0.05 & 3.46 \\
\hline
\end{tabular}

and the lowest production rates of the cruise reported $\left(0.15 \mu \mathrm{mol} \mathrm{C} \mathrm{l}^{-1} \mathrm{~d}^{-1}\right.$ and $0.017 \mu \mathrm{mol} \mathrm{Si} \mathrm{l}^{-1} \mathrm{~d}^{-1}$, at $\left.0 \mathrm{~m}\right)$ the magnitude of the production rates, when integrated to the photic layer, was similar to those at the other stations. This suggests that deeper mixing causes a dilution of phytoplankton biomass by mixing it more evenly through the upper water column, with relatively little effect on the integrated productivity, as suggested by Wilson et al. (1986) for the Ross Sea. We observed an abundance of algae in the brown ice at this station, suggesting a very pre-bloom situation in which most of the autotrophic biomass and productivity are located in the ice rather than in the water.

The measured rates of biogenic silica production per unit of biomass indicate growth rates ranging from 0.12 to 0.29 doublings $\mathrm{d}^{-1}$ for the diatom assemblage (Table 3). The overall mean division rate of 0.23 , although significantly lower than the maximum division rate to be expected at $-2{ }^{\circ} \mathrm{C}$ (ca 0.7 doublings $\mathrm{d}^{-1}$; Eppley 1972), is in good agreement with previous estimates reported from ice-edge phytoplankton blooms in the Ross Sea (Nelson \& Smith 1986, Nelson et al. 1991) and in the Weddell Sea (Quéguiner et al. 1991). We are aware of the potential inaccuracies and biases introduced by this procedure, but it does provide a means by which growth rates can be compared within the bloom. Underestimates of growth rates will occur if significant amounts of detrital silica are present.

\section{DISCUSSION}

\section{Chemical composition of particulate organic matter}

In early spring the particulate organic matter was characterized by especially high POC/chl a ratios, ranging from 73 to $823(\mathrm{~g} / \mathrm{g})$ in the photic layer, the 
lowest values being found in the center of the gyre. The overall mean of 370 suggests that microheterotrophs and detritus comprised a significant fraction of the particulate organic material (Banse 1977). Previous studies have also reported large ranges of variations for $\mathrm{POC} / \mathrm{chl}$ a ratios for Antarctic particulate matter, from 31.8 in a spring bloom (Nelson et al. 1987) to 530 in mid-winter (Cota et al. 1992).

The mean POC/PON mole ratio was $8.2 \pm 0.6$ (Fig. 6), which is somewhat higher than the typical value of 6.6 found by Redfield et al. (1963). It is considerably lower than the ratio of 10.2 reported by Cota et al. (1992) for the Weddell Sea marginal ice zone in winter and comparable to that measured by von Bodungen et al. (1986) for the photic zone of the marginal ice zone of the Antarctic Peninsula in spring.

$\mathrm{BSi} / \mathrm{POC}$ mole ratios reached 0.1 in the upper layer at Stns B1 (coastal station) and B11 (open water) but were $<0.06$ eisewhere. There is no evidence that the $\mathrm{BSi} / \mathrm{POC}$ ratio changed systematically with depth; values were very uniform through the water column and showed little variability throughout the transect. Ratios of vertically integrated $\mathrm{BSi}$ to vertically integrated POC in the photic layer (Table 4) ranged between 0.02 and 0.06 , with a mean of 0.04 . They are in the same range as those reported by Cota et al. (1992) who found a mean $\mathrm{BSi} / \mathrm{POC}$ ratio of 0.05 in the marginal ice zone of the Weddell Sea in winter. This value is lower than any $\mathrm{BSi} / \mathrm{POC}$ ratio reported for productive seasons in the Southern Ocean (e.g. Nelson \& Smith 1986 , Nelson et al. 1987, 1989, Leynaert et al. 1991). Low $\mathrm{BSi} / \mathrm{POC}$ ratios reflect the importance of non-siliceous phytoplankton (Table 2) and the presence of nonsiliceous microheterotrophs in suspended matter, as evidenced by the high $\mathrm{POC} / \mathrm{chl}$ a ratios.

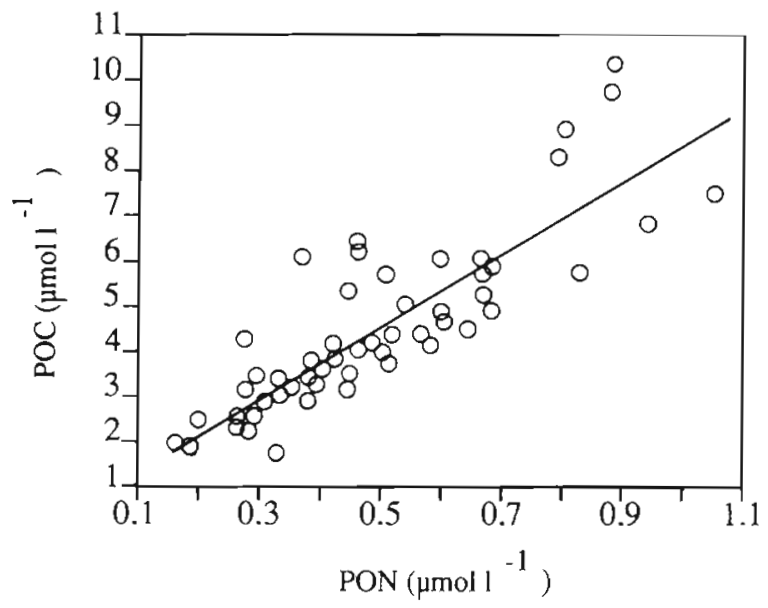

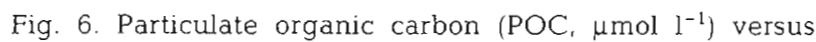
particulate organic nitrogen ( $P O N, \mu \mathrm{mol} \mathrm{l}^{-1}$ ). Regression line (see text)
Table 4. Biogenic silica and particulate organic carbon: comparison of biomasses (BSi/POC) and production (PBSi/PPC) molar ratios. nd: not determined

\begin{tabular}{|lcc|}
\hline Stns & BSi/POC & PBSi/PPC \\
\hline B1 & 0.05 & nd \\
B2 & 0.03 & 0.17 \\
B3 & 0.04 & 0.16 \\
B4 & 0.04 & 0.15 \\
B5 & 0.04 & 0.13 \\
B6 & 0.04 & 0.16 \\
B8 & 0.03 & 0.16 \\
B9 & 0.04 & 0.13 \\
B10 & 0.02 & 0.21 \\
B11 & 0.06 & 0.20 \\
Mean & 0.04 & 0.16 \\
SD & 0.01 & 0.03 \\
\hline
\end{tabular}

The ratio of $\mathrm{BSi}$ production to carbon production (PBSi/PPC) was significantly higher than that for standing stock (Table 4). Large variations in BSi/POC ratios for both standing stocks and primary production have been reported in the Antarctic ecosystems (Nelson \& Smith 1986, Tréguer et al. 1991). To interpret these variations, we advance the following hypothesis:

During winter, phytoplankton is dominated by nonsiliceous species, such as small autotrophic nanoflagellates (Nöthig et al. 1991). Si/C ratios are low (generally $<0.06$; Cota et al. 1992). In early spring, ice melting enhances water-column stability and releases ice algae, some of which survive in the water column (Garrison et al. 1987) and could act as an efficient inoculum to initiate a phytoplankton bloom (Lancelot et al. 1991). But since water-column biomass is still low, $\mathrm{Si} / \mathrm{C}$ biomass ratio is largely influenced by the biogenic matter released from the melting ice, and a large range of variations has been observed: 0.04 to 0.46 (Leynaert unpubl.). This could reflect variations in taxonomic composition of epontic algae or their physiological state (release of dead or senescent phytoplankton). As the phytoplankton bloom develops, Si/C production ratios increase (Nelson \& Smith 1986, Tréguer et al. 1991, this study) and become $>0.13$, the average found by Brezinski (1985) for diatoms in culture grown in nutrient-replete conditions, indicating a shift toward an actively growing, mostly siliceous population. Epontic algae, such as Nitzschia spp., often proliferate (Smith \& Nelson 1985, Wilson et al. 1986, this study).

Then during spring, ecological succession usually leads to a dominance of highly silicified diatoms (Chaetoceros neglectum, Corethron criophilum, Thalassiosira gravida, with mean size $>10 \mu \mathrm{m}$; Jacques $\&$ Panouse 1991). This step of phytoplankton succession corresponds to maximum values of $\mathrm{Si} / \mathrm{C}$ ratios. Mean values reaching 0.65 for biomass and 0.57 for 
production have been encountered in the western Ross Sea during a diatom-dominated ice edge bloom (Nelson \& Smith 1986, Nelson et al. 1987).

In the final step of the succession, we can distinguish 2 different cases:

(a) Intense grazing (Weddell Sea): due to selective feeding by krill on larger cells (Quentin \& Ross 1985), large diatoms are preferentially eaten and biogenic silica is rapidly exported to depth via fecal pellets. Heavy grazing pressure may cause the decline of the bloom and a shift in the species composition of phytoplankton from a diatom-dominated to a nanoflagellatedominated community (Jacques \& Panouse 1991). Si/C ratios diminish. This situation has been clearly observed during Epos2, where the Si/C biomass ratio fell from 0.30 to 0.17 (Leynaert et al. unpubl.) after intense grazing by krill. Cryptophyceans, prymnesiophytes, naked flagellates, green flagellates and small diatoms were identified and $78 \%$ of the total silicic uptake rate was in the $<10 \mu \mathrm{m}$ fraction of suspended matter, indicating that only small diatoms were allowed to remain abundant (Jacques \& Panouse 1991).

(b) Low grazing pressure (Ross Sea): low zooplankton stocks allow large phytoplankton blooms with very

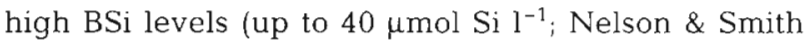
1986). Because of micronutrient limitation (Martin et al. 1990) and/or self shading (Nelson \& Smith 1991), growth rates become lower as the physiological state of the phytoplankton changes. The Si/C production and biomass ratios remain high. This could be explained by the fact that light and micronutrient limitations could both be expected to affect photosynthesis and carbon metabolism more severely than silicification, producing cells with high $\mathrm{Si} / \mathrm{C}$ ratios as a result of organic matter deficiency. Mass sedimentation may cause the decline of the bloom (Smetacek 1985, von Bodungen et al. 1986 in the Bransfield Strait) and the removal of biogenic silica stock from the photic layer.

\section{Estimated annual production of biogenic silica in the northern Weddell Sea}

Table 3 presents the first data on production rates of biogenic silica in partially ice-covered surface waters in the Southern Ocean. Because these data were obtained during the period of maximum solar irradiance (November and December) and show relatively little variability in vertically integrated production rates (Table 3), the mean value of $2.59 \mathrm{mmol} \mathrm{m}^{-2} \mathrm{~d}^{-1}$ provides the best available estimate of the rate of silica production in areas of significant partial ice cover in summer. These rates can be combined with available data from the marginal ice zone (Quéguiner et al. 1991, Tréguer et al. 1991) and from open ocean areas remote from the ice edge (Nelson \& Gordon 1982) to derive an estimate of the annual production of biogenic silica at 60 to $62^{\circ} \mathrm{S}$. The resulting annual estimate can be compared with data on seasonal nutrient depletion (Jennings et al. 1984), annual primary productivity (Smith \& Nelson 1986, Smith et al. 1988) and the seasonal cycle of particulate opal flux (Fischer et al. 1988) from the same region to characterize the major feature of the biogenic silica cycle in the Weddell Sea.

We have estimated the annual silica production in the northern Weddell Sea in a manner similar to that employed in the carbon productivity estimates for the same region derived by Smith \& Nelson (1986) and Smith et al. (1988). The year is divided into 4 characteristically different periods: a winter period of negligible productivity, a well-lit but partially ice-covered period, a bloom period developing after the ice edge has passed, and an open-ocean, deep mixed period in late summer.

\section{Winter}

At 60 to $62^{\circ} \mathrm{S}$, the maximum daily irradiance under cloudless skies would be $<15 \mathrm{E} \mathrm{m}^{-2} \mathrm{~d}^{-1}$ from 1 April through 1 October (Campbell \& Aarup 1989) and clouds further reduce irradiance to an average of ca $5 \mathrm{E} \mathrm{m}^{-2} \mathrm{~d}^{-1}$ for most of this period (Cota et al. 1992), resulting in a light/mixing regime that is highly unfavorable to phytoplankton growth (Nelson \& Smith 1991). In addition, the 60 to $62^{\circ} \mathrm{S}$ zonal band in the Weddell Sea is typically ice-covered from May through September (Zwally et al. 1983), diminishing the light availability in the water column to virtually zero. Our annual silica budget thus assumes negligible production for a 6 mo (April to October) period.

\section{Spring-summer under partial ice cover}

The northern limit of $>15 \%$ ice cover in the Weddell Sea is typically ca $57^{\circ} \mathrm{S}$, with the 60 to $62^{\circ} \mathrm{S}$ zone remaining $>80 \%$ covered from June to September (Zwally et al. 1983). The ice edge begins to retreat in late September or early October, and in 1983 the mean rate of retreat was $5 \mathrm{~km} \mathrm{~d}^{-1}$ through the October to early January period (Nelson et al. 1987). In 1988, a similar rate of retreat (ca $5.5 \mathrm{~km} \mathrm{~d}^{-1}$ ) was observed during December (Leynaert et al. 1991). The mean rate of ice retreat apparently increases significantly during January of most years (Smith et al. 1988). Throughout the October-January period the zone of significant partial ice cover ( 20 to $80 \%$ ) is approximately $300 \mathrm{~km}$ in north-south extent (Zwally et al. 1983); thus a given location in the northern Weddell Sea would be under significant partial ice cover for approximately $60 \mathrm{~d}$ (300 $\mathrm{km}$ at $5 \mathrm{~km} \mathrm{~d}^{-1}$ ) each spring. This period would commence on about 1 October at $60^{\circ} \mathrm{S}$, and later at 
Table 5. Estimated annual production of biogenic silica in the Weddell Sea (estimates for the northern and southern parts calculated separately)

\begin{tabular}{|cccc|}
\hline Period & $\begin{array}{c}\text { Duration } \\
(\mathrm{d})\end{array}$ & $\begin{array}{c}\text { Production } \\
\left(\mathrm{mmol} \mathrm{m}^{-2} \mathrm{~d}^{-1}\right)\end{array}$ & $\begin{array}{c}\text { Total } \\
\left(\mathrm{mol} \mathrm{m}^{-2}\right)\end{array}$ \\
\cline { 1 - 2 } Between 60 and $65^{\circ} \mathrm{S}\left(4.9 \times 10^{6} \mathrm{~km}^{2}\right)$ & \\
Partial ice cover & 60 & 2.60 & 0.16 \\
Ice-edge bloom & 40 & 10.90 & 0.44 \\
Post-bloom & $70-90$ & 3.00 & 0.44 \\
Total & $170-190$ & $4.58-4.76$ & $0.81-0.87$ \\
South of $65^{\circ} \mathrm{S}\left(1.2 \times 10^{6} \mathrm{~km}^{2}\right)$ & & \\
Partial ice cover & 60 & 2.60 & 0.16 \\
Ice-edge bloom & 30 & 10.90 & 0.33 \\
Post-bloom & 60 & 3.00 & 0.18 \\
Total & 150 & 4.47 & 0.67 \\
Total Weddell Sea & & & $0.78-0.83$ \\
\hline
\end{tabular}

more southerly locations. The mean rate of silica production in this zone is taken to be $2.6 \mathrm{mmol} \mathrm{m} \mathrm{m}^{-2} \mathrm{~d}^{-1}$ (see Table 3), resulting in an integrated silica production of ca $160 \mathrm{mmol} \mathrm{m} \mathrm{m}^{-2}$ for the $60 \mathrm{~d}$ period (Table 5).

\section{Ice-edge phytoplankton bloom}

As is the case in many other seasonally ice-covered regions of the ocean (e.g. Niebauer \& Alexander 1985 , Smith \& Nelson 1985), a phytoplankton bloom typically develops in the open water seaward of the receding ice edge in the Weddell Sea (Nelson et al. 1987). The north-south extent of this bloom was ca $200 \mathrm{~km}$ in 2 spatial studies of biomass distributions in different years (Nelson et al. 1987, Leynaert et al. 1991). Silica production rates have been measured in ${ }^{30} \mathrm{Si}$ and ${ }^{32} \mathrm{Si}$ tracer studies in the marginal ice zone of the Weddell Sea in spring (Quéguiner et al. 1991, Tréguer et al. 1991), and are significantly higher than those we report here for the zone of partial ice cover; they range from 6.0 to $20.0 \mathrm{mmol} \mathrm{m}^{-2} \mathrm{~d}^{-1}$, with a mean of 10.9 . Using the $5 \mathrm{~km} \mathrm{~d}^{-1}$ rate of ice retreat discussed above, the bloom would be present at any fixed location for approximately $40 \mathrm{~d}\left(200 \mathrm{~km}\right.$ at $\left.5 \mathrm{~km} \mathrm{~d}^{-1}\right)$, resulting in an integrated production of ca $440 \mathrm{mmol} \mathrm{m} \mathrm{m}^{-2}$ during the bloom.

\section{Post-bloom period}

Using the approximations developed above, the ice edge and associated bloom have typically moved to the south of $60^{\circ} \mathrm{S}$ by early January, and to the south of $62^{\circ} \mathrm{S}$ by late January. Phytoplankton blooms are exceptionally rare or absent in open water remote from the ice edge (e.g. Holm-Hansen et al. 1977, Lancelot et al. 1991), and recent calculations suggest that chloro- phyll concentrations exceeding ca $1 \mu \mathrm{g} \mathrm{I}^{-1}$ may not be sustainable because of the relatively deep mixed surface layers present (Smith \& Nelson 1986). However, the integrated daily solar irradiance is near its annual maximum in early January and does not begin to decrease rapidly until late February (e.g. Campbell \& Aarup 1989). Thus, some production of biogenic silica almost undoubtedly continues in the open-ocean regions of the Weddell Sea through the late summer. No data on silica production rates in this portion of the system are available, and the production during the openocean period following the bloom is the most uncertain term in our annual budget. However, Nelson \& Gordon (1982) reported silica production rates ranging from 0.9 to $6.8 \mathrm{mmol} \mathrm{m}^{-2} \mathrm{~d}^{-1}$ (mean 3.0 ) in the open waters of the Pacific sector of the ACC in October. October is seasonally symmetrical with February with respect to solar irradiance, and we will use the $3.0 \mathrm{mmol} \mathrm{m} \mathrm{m}^{-2} \mathrm{~d}^{-1}$ as a provisional mean rate. The open-ocean period lasts approximately $90 \mathrm{~d}$ (early January through late March) at $60^{\circ} \mathrm{S}$, and $70 \mathrm{~d}$ (late January through late March) at $62^{\circ} \mathrm{S}$ as a result of the later passage of the ice edge. Thus our estimate of the integrated silica production in open water following the ice-edge bloom ranges from $210 \mathrm{mmol} \mathrm{m}^{-2}$ at $62^{\circ} \mathrm{S}$ to $270 \mathrm{mmol} \mathrm{m}^{-2}$ at $60^{\circ} \mathrm{S}$.

The calculations described above are summarized in Table 5. The resulting estimate of the annual rate of biogenic silica production in the northern Weddell Sea is 810 to $870 \mathrm{mmol} \mathrm{m}-2 \mathrm{yr}^{-1}$. We believe this estimate is conservative because it assumes zero production from April through September and because no production rate data are available from the marginal ice zone in late summer, when the bloom is likely to be more intense than it is in November and December. Jennings et al. (1984), using data on seasonal nutrient depletion, calculated an integrated silica production rate of $850 \mathrm{mmol} \mathrm{m}^{-2}$ in the Weddell Sea at $60^{\circ} \mathrm{S}$ for the period from the first appearance of open water until late January. We believe that estimate and ours to be in good agreement. The annual rate of silica production that we estimate for the northern Weddell Sea is about one third as high as has been estimated for the Ross Sea, where a very intense ice-edge diatom bloom develops and silica production rates often exceed $30 \mathrm{mmol} \mathrm{m} \mathrm{m}^{-2} \mathrm{~d}^{-1}$ in summer (Jones et al. 1990, Nelson et al. 1991).

\section{Cycling of biogenic silica in the Weddell Sea: an anomaly in the Southern Ocean?}

The estimate of annual production of biogenic silica in the northern Weddell Sea that we have derived from ${ }^{29} \mathrm{Si},{ }^{30} \mathrm{Si}$ and ${ }^{32} \mathrm{Si}$ tracer data (Table 5) and the earlier 
estimate made by Jennings et al. (1984) from seasonal nutrient depletion in the surface layer both indicate that the production rate must exceed $810 \mathrm{mmol} \mathrm{m}^{-2} \mathrm{yr}^{-1}$. In contrast, studies of the vertical flux of opal through the water column based on long-term deployment of sediment traps at several locations in the Weddell Sea indicate that the flux to depths of 800 to $900 \mathrm{~m}$ is no more than $5 \mathrm{mmol} \mathrm{m}^{-2} \mathrm{yr}^{-1}$ (e.g. Fischer et al. 1988, Honjo 1991). The seasonality of the particle flux collected by traps matches the apparent seasonal cycle of biogenic silica production to a certain degree: there is a single strong maximum in summer, although the flux maximum appears to occur 1 to 2 mo later than the calculated maximum in productivity. The quantitative picture of the regional silica cycle that emerges from these studies, when taken together, is that $<1 \%$ of the silica produced annually by phytoplankton in the upper ocean reaches a depth of $800 \mathrm{~m}$. Although benthic fluxes of silicic acid calculated by Rutgers van der Loeff \& van Bennekom (1989) do not match these sediment trap data, these authors also support the idea that biogenic silica fluxes in the central Weddell Sea are significantly lower than in other areas of the ACC.

This relationship between production and flux suggests that the recycling of biogenic silica in the Weddell Sea must be dramatically different from that in the rest of the Southern Ocean (Table 6). Nelson \& Gordon (1982) compared rates of silica production measured in the surface waters of the ACC with DeMaster's (1981) data on opal accumulation rates in Southern Ocean sediments and concluded that at least $20 \%$ of the annual silica production must reach the sea floor (typically at depths of 3000 to $5000 \mathrm{~m}$ ). A recent coordinated study of biogenic silica cycling in the water column and sediments of the western Ross Sea has developed a regional silica budget which suggests that over $25 \%$ of the silica produced annually by diatoms, and ca $65 \%$ of the net silica production (production in excess of redissolution in the upper $50 \mathrm{~m}$ ), is delivered to the seabed at depths of 600 to $700 \mathrm{~m}$ (Nelson et al. 1991, DeMaster et al. in press). Particle flux data from long-term sediment-trap deployments on the Ross Sea shelf also indicate that the annual opal flux to depths $35 \mathrm{~m}$ above the bottom is in the range of

Table 6. Cycling of biogenic silica in the Southern Ocean Is the Weddell Sea atypical?

\begin{tabular}{|lccc|}
\hline & $\begin{array}{c}\text { Production } \\
\left(\mathrm{mol} \mathrm{m}^{-2} \mathrm{yr}^{-1}\right)\end{array}$ & $\begin{array}{c}\text { Accumulation } \\
\left(\mathrm{mol} \mathrm{m}^{-2} \mathrm{yr}^{-1}\right)\end{array}$ & $\begin{array}{c}\text { Acc./prod. } \\
(\%)\end{array}$ \\
\hline Weddell Sea & 0.8 & 0.005 & $<1 \%$ \\
Ross Sea & $2.0-3.0$ & 1.060 & $35-50 \%$ \\
$\mathrm{ACC}$ & $0.5-0.8$ & 0.200 & $25-40 \%$ \\
\hline
\end{tabular}

25 to $50 \%$ of the annual surface production (DeMaster et al. in press). On a large scale, sediment south of the Antarctic Polar Front has been identified as the main present site of opal accumulation in the oceans (e.g. DeMaster 1981, Ledford-Hoffman et al. 1986), despite the fact that the annual primary productivity of the Southern Ocean is quite low (El-Sayed 1978, Smith et al. 1988). This relationship would not be possible unless the fraction of surface-produced silica reaching the sea floor is considerably higher than the global average, wich has been estimated to be 2 to $5 \%$ (Calvert 1983).

The modern sediments of the Southern Ocean are rich in opal (50 to $80 \%$ by weight) in a circumpolar band extending $80 \%$ of the distance around the $\mathrm{ACC}$, with one notable gap from ca 25 to $85^{\circ} \mathrm{W}$ (DeMaster 1981). The gap is in the region of the Drake Passage, Scotia and western Weddell Seas, and thus includes the area where we calculate that $<1 \%$ of the annual silica production reaches a depth of $800 \mathrm{~m}$. The available data on biogenic silica production in the Weddell Sea (Quéguiner et al. 1991, Tréguer et al. 1991, this study) indicate that silica production by diatoms proceeds at rates that are reasonably high for the Southern Ocean, especially in the marginal ice zone. Thus, the low opal content of sediments in the Weddell Sea appears to result from the almost complete redissolution of silica in the upper kilometer of the ocean, rather than from low rates of production in the euphotic zone or from near-bottom processes.

It is not immediately clear what conditions in the Weddell Sea might make the biogeochemistry of siliceous material so very different from that in the Ross Sea and in most of the ACC. It is known that there is a complex microheterotrophic food web in the marginal ice zone of the Weddell Sea in summer (e.g. Hewes et al. 1985, Garrison \& Buck 1989), and microzooplankton grazing on heavily silicified diatoms could result in much more intense recycling (and hence less vertical transport) of both organic and siliceous material than would be the case if most grazing were carried out by larger metazoans. Honjo (1991) noted that most of the biogenic particle flux in the northern Weddell Sea is in the form of 'relatively fast-sinking, more protected fecal pellets', and that this flux is very low in comparison with that in the other major oceans. The relative importance of micro- and macroheterotrophic grazers is not clearly understood in any subsystem of the Southern Ocean, but if microzooplankton are far more important in the Weddell Sea than in the Ross Sea or the ACC at large it would help to explain the unusually intense recycling suggested by the relationship between silica production and vertical silica flux.

Alternatively, van Bennekom et al. (1991) have suggested that the dissolution rate of biogenic silica in the 
water column of the Southern Ocean may be considerably higher than expected for cold water because of a low $\mathrm{Al} / \mathrm{Si}$ ratio in the siliceous particles. Their data and experimental materials were obtained entirely from the Weddell and Scotia Seas: if the Al/Si ratio of diatoms in this region is significantly lower than in other areas of the Southern Ocean the lower ratio could, in principle, result in less efficient preservation of silica through the water column.

The 2 explanations offered above are not mutually exclusive. The unusual quantitative relationship among silica production, vertical silica transport and sediment composition in the Weddell Sea may result from the combined effects of food-web structure and particle chemistry, or from some other condition that has not yet been identified. Regardless of the mechanism, however, it appears that the cycling of biogenic silica in the upper water column of the Weddell Sea is very different from that in the rest of the Southern Ocean and that this difference is accurately recorded in the sediments.

\section{New silica budget for the Southern Ocean}

The data on silica production rates in ice-covered waters in early spring (Table 3 ) enable us to improve estimates of the annual silica production in the Southern Ocean. Table 7 presents a revised estimate of the annual BSi production in the Southern Ocean, based on information from 3 characteristically different systems: the Weddell Sea, the Coastal and Continental Shelf Zone (CCSZ) (both of which experience seasonal ice cover), and the permanently ice-free waters of the ACC.

To estimate a budget, the Weddell Sea is somewhat arbitrarily defined as the entire oceanic region adjoining the Antarctic continent between $60^{\circ} \mathrm{W}$ and $20^{\circ} \mathrm{E}$ and south of $60^{\circ} \mathrm{S}$. The northern limit coincides reasonably well with the maximum extent of $>80 \%$ ice cover in September in this area (Zwally et al. 1983).

Table 7. New silica budget for the Southern Ocean

\begin{tabular}{|c|c|c|c|c|}
\hline Area & $\begin{array}{l}\text { Surface } \\
\left(\mathrm{km}^{2}\right)\end{array}$ & $\begin{array}{l}\text { Production } \\
\left(\mathrm{mol} \mathrm{m}^{-2} \mathrm{yr}^{-1}\right)\end{array}$ & $\begin{array}{c}\text { Total } \\
\left(\text { Tmol } \mathrm{yr}^{-1}\right)\end{array}$ & $\%$ Total \\
\hline $\begin{array}{l}\text { Weddel]. } \\
\text { Sea }\end{array}$ & $6.10 \times 10^{6}$ & 0.8 & 4.9 & $15-43$ \\
\hline $\begin{array}{l}\text { Continental } \\
\text { shelves }\end{array}$ & $9.20 \times 10^{5}$ & 3.5 & $0.6-3.2$ & $3-23$ \\
\hline $\mathrm{ACC}$ & $3.00 \times 10^{7}$ & $0.2-0.8$ & $6.0-24.0$ & $42-81$ \\
\hline $\begin{array}{l}\text { Antarctic } \\
\text { Ocean }\end{array}$ & $3.70 \times 10^{7}$ & $0.3-0.8$ & $11.5-32.1$ & \\
\hline
\end{tabular}

This definition reflects more a biological ensemble than any regime of circulation or hydrography. The method described above to estimate annual BSi production can be extended as far south as $65^{\circ} \mathrm{S}$ (see Table 5). However, south of $65^{\circ} \mathrm{S}$ the ice-free period is shorter and the length of each different period of productivity is thus affected. This area is mostly icecovered until early January, and is permanently icecovered in the western part. In February, after having reached its minimum extent, the ice begins to advance again, cutting short the ice-edge bloom and the afterbloom periods to about 30 and $40 \mathrm{~d}$ respectively. Calculations are summarized in Table 5 and give an estimated annual BSi productivity ranging from 0.81 to $0.87 \mathrm{~mol} \mathrm{~m}^{-2} \mathrm{yr}^{-1}$ for the northern Weddell Sea and of $0.67 \mathrm{~mol} \mathrm{~m}{ }^{-2} \mathrm{yr}^{-1}$ for the southern part. Accounting for the permanently ice-covered region in the southwestern Weddell Sea, where productivity must remain very low at all times, these rate estimates yield a total BSi production of 4.7 to $5.0 \mathrm{Tmol} \mathrm{Si} \mathrm{yr}^{-1}$ for the Weddell Sea.

BSi production data for the CCSZ come only from the Ross Sea, which is the only continental-shelf area in the Antarctic that has been extensively studied. Nelson \& Smith (1986) reported the highest BSi production rates ever encountered in the Southern Ocean: $2.3 \mathrm{~mol}$ $\mathrm{m}^{-2} \mathrm{yr}^{-1}$, and this estimates has now been revised upward to $3.5 \mathrm{~mol} \mathrm{~m}^{-2} \mathrm{yr}^{-1}$ by including data from later in the spring production season (DeMaster et al, in press). Thus if the Ross Sea is typical of the CCSZ with respect to silica production, this region is a significant term in the Southern Ocean total in spite of its small surface area (Table 7 ). We have estimated the overall annual silica production in the CCSZ by assuming that it ranges between 2 limits: the lower limit is obtained taking into account only the production in the Ross Sea and assuming that the production is negligible anywhere else in the CCSZ (i.e. by applying the $3.5 \mathrm{~mol}$ $\mathrm{m}^{-2} \mathrm{yr}^{-1}$ value only to the $1.6 \times 10^{5} \mathrm{~km}^{2}$ area of the Ross Sea shelf). The upper limit is obtained by extrapolating the BSi production of the Ross Sea to the entire CCSZ, an area of approximately $9.2 \times 10^{5} \mathrm{~km}^{2}$.

The ACC is known to be an area of low productivity and many satellite images have confirmed that idea (e.g. Smith \& Sakshaug 1990, Mitchell et al. 1991). The only data available on silica production rates in the open waters of the ACC were obtained in October (Nelson \& Gordon 1982), and these averaged $3 \mathrm{mmol}$ $\mathrm{m}^{-2} \mathrm{~d}^{-1}$. Without more seasonal information, especially from mid summer, it is virtually impossible to derive an annual estimate from the available direct measurements, so we have attempted to place upper and lower limits on this term from indirect information. As a first approximation, we can consider that the maximum annual rate of silica production in the 
oceanic region influenced by the seasonal ice retreat should not be higher than that it is in areas that experience an ice-edge phytoplankton bloom. Thus, we took our estimate of the annual silica production in the northern Weddell Sea $\left(0.8 \mathrm{~mol} \mathrm{Si} \mathrm{m} \mathrm{m}^{-2} \mathrm{yr}^{-1}\right.$; see previous section) as an upper limit. As a lower limit, we took primary productivity data from El Sayed (1978) $16 \mathrm{gC} \mathrm{m}^{-2} \mathrm{yr}^{-1}$ (= $\left.1.3 \mathrm{~mol} \mathrm{C} \mathrm{m} \mathrm{mr}^{-2}\right)$ and converted this value to an estimated rate of silica production using a BSi/POC ratio of 0.13 (Brzezinski 1985). The resulting lower limit is $0.2 \mathrm{~mol} \mathrm{Si} \mathrm{m}^{-2} \mathrm{yr}^{-1}$, or onefourth of the maximum estimate. The culture-derived $\mathrm{BSi} / \mathrm{POC}$ ratio of 0.13 pertains only to diatoms (Brzezinski 1985), and still lower estimates of silica production in the ACC could be obtained by using a lower ratio to characterize the mixed phytoplankton assemblages of the region. However, BSi/POC ratios $<0.13$ in Southern Ocean surface waters have been reported only in the unproductive winter period and in ice-covered waters (e.g. Cota et al. 1992; see also Table 4), and considerably higher values are commonly observed in spring and summer (e.g. Nelson et al. 1989)

The resulting annual estimate for the Southern Ocean (Table 7) presents what we believe to be a range that represents the highest and lowest estimates that can be reasonably supported by the available data, rather than a single estimate of the annual BSi production of the Southern Ocean. The range we calculate in this way, ca 11.7 to $32.1 \mathrm{Tmol} \mathrm{Si} \mathrm{yr}^{-1}$, is lower than in previous works. For example, it is only about 25 to $65 \%$ of the estimate recently obtained by Tréguer \& van Bennekom (1991). If we compare our data to the carbon productivity estimate of Smith et al. (1988; $1 \mathrm{Gt} C \mathrm{yr}^{-1}$, which equates to ca $83 \mathrm{Tmol} \mathrm{C} \mathrm{yr}^{-1}$ ) we obtain a PBSi/PPC ratio for the Antarctic phytoplankton ranging from 0.14 to 0.39 . Comparison with the more recent primary production estimate of Lancelot et al. (1991) gives lower ratios, ranging from 0.07 to 0.20 . Both of these results are in a range that is consistent with field data. The large uncertainties remaining are primarily a result of uncertainties for the $\mathrm{ACC}$, where we cannot yet estimate the annual rate of silica production from direct measurements, but which appear from indirect estimates (Table 7 ) to account for about 45 to $80 \%$ of the total.

Acknowledgements. We thank E. Fahrbach, chief scientist of the ANT IX/2 cruise; the officers and crew of the RV 'Polarstern'; Lou Gordon, Andy Ross and Jim Kress for the nutrient data; Olivier Ragueneau for his help at sea; and Annick Masson and Julie Arrington for their technical assistance.

\section{LITERATURE CITED}

Alpkem Corp. (1986). Silicate, A303-S220. Preliminary RFA/2 Rapid flow analyser operator's manual. Portland, OR

Banse, K. (1977). Determining the carbon to chlorophyll ratio of natural phytoplankton. Mar. Biol. 41: 199-212

Brzezinski, M. A. (1985). The Si/C/N ratios of marine diatoms: interspecific variability and the effect of some environmental variables. J. Phycol. 21: 345-357

Calvert, S. E. (1983). Sedimentary geochemistry of silicon. In: Aston, S. R. (ed.) Silicon geochemistry and biogeochemistry. Academic Press, London, p. 143-186

Campbell, J. W., Aarup, T. (1989). Photosynthetically available radiation at high latitudes. Limnol. Oceanogr. 34(8): $1490-1499$

Carmack, E. C., Foster, T. D. (1975). On the flow of water out of the Weddell Sea. Deep Sea Res. 22: 711-724

Cota, G. F., Smith, W. O. Jr, Nelson, D. M., Muench, R. D., Gordon, L. I. (1992). Nutrient and biogenic particulate distributions, primary productivity and nitrogen uptake in the Weddell-Scotia Sea Marginal Ice Zone in winter. J. mar. Res. 50; 155-181

DeMaster, D. Jr (1981). The supply and accumulation of silica in the marine environment. Geochim. Cosmochim. Acta 45: $1715-1732$

DeMaster, D. J., Dunbar, R. B., Nelson, D. M., Nittrouer, C. A., Smith, W. O. Jr (in press). The cycling and accumulation of organic matter and biogenic silica in a high-latitude environment: the Ross Sea. Oceanography

DeMaster, D. J. Jr, Nelson, T. M., Harden, S. L., Nittrouer, C. A. (1991). The cycling and accumulation of biogenic silica and organic carbon in Antarctic deep-sea and continental margin environments. Mar. Chem. 35: 489-502

El-Sayed, S. Z. (1978). Primary productivity and estimates of potential yields of the Southern Ocean. In: McWhinnie, M. A. (ed.) Polar research. Westview, New York, p. 141-160

Eppley, R. W. (1972). Temperature and the regulation of phytoplankton growth in the sea. Fish. Bull. U.S. 70: 1063-1085

Fahrbach, E., Knoche, M., Rohardt, G. (1991). An estimate of water mass transformation in the southern Weddell Sea. Mar. Chem. 35: 25-44

Fischer, G., Fütterer, D., Gersonde, R., Honjo, S., Ostermann, D., Wefer, G. (1988). Seasonal variability of particle flux in the Weddell Sea and its relation to ice cover. Nature 335: $426-428$

Foster, T. D., Carmack, E. C. (1976). Frontal zone mixing and Antarctic bottom water formation in the southern Weddell Sea. Deep Sea Res. 23: 301-307

Frontier, S. (1969). Méthode d'analyse statistique applicable à l'écologie du plancton. Doc. Sci. ORSTOM, Nosy-Bé, 7

Garrison, D. L., Buck, K. R. (1989). Protozooplankton in the Weddell Sea, Antarctica: abundance and distribution in the ice-edge zone. Polar Biol. 9: 341-351

Garrison, D. L., Buck, K. R., Fryxell, G. A. (1987). Algal assemblages in Antarctic pack ice and in ice edge-plankton. J. Phycol. 23: 564-572

Hewes, C. D., Holm-Hansen, O., Sakshaug, E. (1985). Alternate carbon pathways at lower trophic levels in the Antarctic food web. In: Siegfried, W. R., Condy, P. R., Laws, R. M. (eds.) Antarctic nutrient cycles and food webs. Springer-Verlag, Berlin, p. 277-283

Holm-Hansen, O., El-Sayed, S. Z., Franceschini, G. A., Cuhel, R. L. (1977). Primary production and the factors controlling phytoplankton growth in the Southern Ocean. In: Llano, G. (ed.) Adaptations within Antarctic ecosystems. Gulf, Houston, p. 11-50 
Honjo, S. (1991). Particles fluxes and modern sedimentation in the Polar Oceans. In: Smith, W. O. Jr (ed.) Polar oceanography. Academic Press, New York, p. 687-740

Jacques, G., Panouse, M. (1991). Biomass and composition of size fractionated phytoplankton in the Weddell-Scotia Confluence area. Polar Biol. 11: 315-328

Jennings, J. C., Gordon, L. I., Nelson, D. M. (1984). Nutrient depletion indicates high primary productivity in the Weddell Sea. Nature 309: 51-54

Jones, E. P., Nelson, D. M., Tréguer, P. (1990). Chemical oceanography. In: Smith, W. O. Jr (ed.) Polar oceanography. Academic Press, New York, p. 407-476

Lancelot, C., Billen, G., Veth, C., Becquevort, S., Mathot, S. (1991). Modelling carbon cycling through phytoplankton and microbes in the Scotia-Weddell Sea area during sea ice retreat. Mar. Chem. 35: 305-324

Ledford-Hoffman, P. A., DeMaster, D. J., Nittrouer, C. A. (1986). Biogenic silica accumulation in the Ross Sea and the importance of Antarctic continental shelf deposits in the marine silica budget. Geochim. Casmochim. Acta 50 : 2099-2110

Leynaert, A., Tréguer, P., Quéguiner, B., Morvan, J. (1991). The distribution of biogenic silica and the composition of particulate organic matter in the Weddell-Scotia Sea during spring 1988. Mar. Chem. 35: 435-447

Martin, J. H., Fitzwater, S. E., Gordon, R. M. (1990). Iron deficiency limits phytoplankton growth in Antarctic waters. Global biochem. Cycles 4: 5-12

MitchelI, B. G., Brody, E. A., Holm-Hansen, O., McClain, C., Bishop, P. (1991). Light limitation of phytoplankton biomass and macronutrient utilization in the Southern Ocean. Limnol. Oceanogr. 36: 1662-1677

Muench, R. D. (1990). Mesoscale phenomena in the Polar Oceans. In: Smith, W. O. Jr (ed.) Polar oceanography. Academic Press, New York, p. 223-286

Nelson, D. M., Ahern, A. J., Herlihy, L. J. (1991). Cycling of biogenic silica within the upper water column of the Ross Sea. Mar. Chem. 35: 461-476

Nelson, D. M., Brzezinski, M. A. (1990), Kinetics of silicic acid uptake by natural diatom assemblages in two Gulf-Stream warm-core rings. Mar. Ecol. Prog. Ser. 62: 283-292

Nelson, D. M., Goering, J. J. (1977). A stable isotope tracer method to measure silicic acid uptake by marine phytoplankton. Analyt. Biochem. 78: 139-147

Nelson, D. M., Gordon, L. I. (1982). Production and pelagic dissolution of biogenic silica in the Southern Ocean. Geochim. Cosmochim. Acta. 46: 491-501

Nelson, D. M., Smith, W. O. (1986). Phytoplankton bloom dynamics of the western Ross Sea ice edge - II. Mesoscale cycling of nitrogen and silicon. Deep Sea Res. 33: $1389-1412$

Nelson, D. M., Smith, W. O. Jr (1991). Sverdrup revisited: Critical depths, maximum chlorophyll levels, and the control of Southern Ocean productivity by the irradiancemixing regime. Limnol. Oceanogr. 36: 1650-1661

Nelson, D. M., Smith, W. O, Gordon, L. I., Huber, B. A. (1987) Spring distribution of density, nutrients, and phytoplankton biomass in the ice edge zone of the Weddell-Scotia Sea. J. geophys. Res. 92: 7181-7190

Nelson, D. M., Smith, W. O., Muench, R. D., Gordon, L. I., Sullivan, C. W. Husby, D. M. (1989). Particulate matter and nutrient distributions in the ice-edge zone of the Weddell Sea: relationship to hydrography during late summer. Deep Sea Res. 36: 191-209

Neveux, J. (1976). Dosage de la chlorophylle a et de la phéophytine par fluorométrie. Annls Inst. océanogr., Paris 52: $165-174$
Niebauer, H. J., Alexander, V. (1985). Observations and significance of ice-edge oceanographic frontal structure in the Bering Sea. Cont. Shelf Res. 4:367-388

Nöthig, E. M., Bathmann, U., Jennings, J. C., Fahrbach, E., Gradinger, R., Gordon, L. I., Makarov, R. (1991). Regional relationships between biological and hydrographical properties in the Weddell Gyre in late austral winter 1989. Mar. Chem. 35: 325-336

Paasche, E. (1973). Silicon and the ecology of marine plankton diatoms. 1. Thalassiosira pseudonana (Cyclottella nana) grown in a chemostat with silicate as the limiting nutrient. Mar. Biol. 19: 117-126

Quéguiner, B., Tréguer, P., Nelson, D. M. (1991). The production of biogenic silica in the Weddell and Scotia Seas. Mar. Chem. 35: 449-459

Quentin, L. B., Ross, R. M. (1985). Feeding by Antarctic krill Euphausia superba: does size matter ? In Siegfried, W. R. Condy, P. R., Laws, R. M. (eds.) Antarctic nutrient cycles and food webs. Springer-Verlag, Berlin, p. 372-377

Redfield, A. C., Ketchum, B., Richards, F. A. (1963). The influence of organisms on the composition of seawater. In: Hill, M. N. (ed.) The sea, Vol. 2. Wiley Interscience, New York, p. $26-77$

Rutgers van der Loeff, M. M., van Bennekom, A. J. (1989). Weddell Sea contributes little to silica enrichment in Antarctic bottom water. Deep Sea Res. 36: 1341-1357

Smetacek, V. S. (1985). Role of sinking in diatom life-history cycles: ecological, evolutionary and geological significance. Mar. Biol. 84: 239-251

Smith, W. O., Nelson, D. M. (1985). Phytoplankton bloom produced by a receding ice edge in the Ross Sea: spatial coherence with the density field. Science 227 $163-166$

Smith, W. O., Nelson, D. M. (1986). The importance of iceedge phytoplankton blooms in the Southern Ocean. BioSci. 36: 251-257

Smith, W. O. Jr, Keene, N. K., Comiso, J. C. (1988). Interannual variability in estimated primary production of Antarctic marginal ice zone. In: Sahrhage, D. (ed.) Antarctic ocean and resources variability. SpringerVerlag. Berlin, p. 131-139

Smith, W. O. Jr, Sakshaug, E. (1990). Polar phytoplankton. In: Smith, W. O. Jr (ed.) Polar oceanography, Part B Academic Press, San Diego, p. 477-525

Strickland, J. D. H., Parsons, T R. (1972). A practical handbook of seawater analysis, 2nd edn. Bull. Fish. Res. Bd Can. 167

Tréguer, P., Jacques, G. (1992). Dynamics of nutrients and phytoplankton, and fluxes of carbon, nitrogen and silicon in the Antarctic Ocean. Polar Biol. 12: in press

Tréquer, P., Lindner, L., van Bennekom, A. J., Leynaert, A. Panouse, M., Jacques, G. (1991). Production of biogenic silica in the Weddell-Scotia Seas measured with ${ }^{32} \mathrm{Si}$. Limnol. Oceanogr. 36: 1217-1227

Tréguer, P., Nelson, D. M., Gueneley, S., Zeyon, C., Morvan, J., Buma, A. (1990). The distribution of biogenic and lithogenic silica and the composition of particulate organic matter in the Scotia Sea and the Drake Passage during autumn 1987. Deep Sea Res. 37: 833-851

Tréguer, P., van Bennekom, A. J. (1991). The annual production of biogenic silica in the Antarctic Ocean. Mar. Chem. 35: $477-487$

Utermöhl, H. (1931). Neue Wege in der quantitativen Erfassung des Planktons (mit besonderer Berücksichtigung des Ultraplanktons). Verh. int. Verein theor. angew. Limnol. 5: 567-596

van Bennekom, A. J., Buma, A. G. J., Nöthing, R. F. (1991). 
Dissolved aluminium in the Weddell-Scotia Confluence and effect of $\mathrm{Al}$ on the dissolution kinetics of biogenic silica. Mar. Chem. 35: 423-434

von Bodungen, B. V., Smetacek, V. S., Tilzer, M. M., Zeitzschel, B. (1986). Primary production and sedimentation during spring in the Antarctic Peninsula region. Deep Sea Res. 33: 177-194

This article was submitted to the editor
Wilson, D. L., Smith, W. O. Jr, Nelson, D. M. (1986). Phytoplankton bloom dynamics of the western Ross Sea ice edge. I. Primary productivity and species-specific production. Deep Sea Res. 33: 1375-1387

Zwally, H. J., Parkinson, C. L., Comiso, J. C. (1983). Variability of Antarctic sea ice and changes in carbon dioxide. Science 220: 1005-1012

Manuscript first received: July 29, 1992

Revised version accepted: March 15, 1993 